\title{
VAT and Tax Credits: A Way to Eliminate Tax-Evasive Use of Transfer Prices?"
}

\author{
Tomáš BUUS * Jaroslav BRADA **
}

Literature on transfer pricing was quite rare for a long time - until the 7th decade of the 20th century. One for all we shall mention (Smalenbach, 1908/1909) and (Hirshleifer, 1956), which created the theoretical base for further research. With the grow of importance of multinational enterprises (MNEs) and economical globalization the significance of transfer pricing issues grows. The obstacle to better understanding of transfer pricing is that transfer pricing is considered to be confidential issue at most MNEs. Thus empirical studies are rare, though number of theoretically aimed articles in the recent past (nineties of the 20th century) is pleasant.

Both the newer and the older literature deals mainly with the following problems:

1. the general problems of central setting of the transfer price,

2. preference of the system of transfer pricing (centralized or decentralized),

3. impact of information asymmetry and managers' compensation,

4. optimization of transfer pricing with respect to taxes and other criteria,

5. regulation of transfer pricing.

\# The article is processed as an output of a research project Regulation of Transfer Pricing registered by the Czech Science Foundation under the registration number 402/08/0271.

Ing. Tomáš Buus, Ph.D. - assistant professor; Department of Corporate Finance and Valuation, Faculty of Finance and Accounting, University of Economics, Prague, W. Churchill sq. 4, 13067 Prague, Czech Republic; 〈buust @ vse.cz>.

** Doc. Ing. Jaroslav Brada, Ph.D. - associate professor; Department of Monetary Theory and Policy, Faculty of Finance and Accounting, University of Economics, Prague, W. Churchill sq. 4, 13067 Prague, Czech Republic; <brada@vse.cz>. 
The first mentioned theme has been discussed in the literature quite a long time, but we are afraid to say that in most cases it is a solution based on using of similar methods and assumptions (which are sometimes widened or narrowed), but the results are in most cases similar to the pioneering articles, from the point of view of the conclusions of general problems of transfer pricing. Due to articles (Smallenbach, 1908/1909) and newly (Hirshleifer, 1956) are still in the microeconomic textbooks used theses that the most appropriate transfer price in the vertically integrated MNE are the marginal costs of intermediate product. We can give some examples like (Pappas a Brigham a Hirschey, 1983), (Soukup, 2003) or (Baldenius and Melumad and Reichelstein, 2004) as examples. This theory is in our opinion in contrast with the contemporary business practice and it is based on assumptions, which do not hold in practice. The evident collision of the marginal cost transfer pricing theory can be shown in case of (OECD, 2001). We have concluded in (Buus and Brada, 2008a) that the optimal transfer price from the point of view of resource allocation and efficient production of intermediate product is under neoclassical assumptions the average cost of intermediate product.

The methods of transfer pricing advised to be used in OECD countries are (among others):

1. arms-length method,

2. cost plus method,

3. formula apportionment method,

4. profit split method,

which in all cases directly or indirectly use a premise that the fair transfer price is on the level of price achieved at the market transaction, which equals to marginal cost only in the extraordinary cases (perfectly competitive market of the intermediate product). If there is no market for intermediate product, the cost-plus method is used, which does not use marginal cost, but the average cost of intermediate product. These can be also the optimal solution, which does not require some necessary conditions used or implied by articles deriving the optimality of marginal cost transfer pricing, as Buus and Brada (2008a) show.

Otherwise the contemporary literature aims rather on the information asymmetry, integration of manager's and tax objectives or setting of the optimal transfer price with respect to the particular problems of financial management. 
The problem of transfer prices and their effect on the possibility of active fiscal policy is compelling as Bartelsman and Beetsma (2003) show. Nevertheless the number and size of possible tax evasions is greater at commodities, which are not standardized (not quoted), whereas at the commodities traded at the commodity exchanges the variance of transfer price and difference between transfer price and arms-length price is substantially smaller (Bernard a Jensen and Schott, 2006), which can be nevertheless interpreted similarly as some of the conclusions of (Gresik, 2001) - there, where the MNE has an advantage against the tax authority due to the information asymmetry, is the space for larger tax evasions. Even the measurement becomes a problem in the contemporary globalized world, because the size of transactions inside MNE is so tremendous that it influences the benchmarks used for derivation of armslength price (Eden and Rodrigues, 2004).

Indeed the situation is worsened by governments themselves, because due to the attempt to achieve as high as possible tax income they continuously tighten transfer pricing regulation rules, which leads to the double taxation and depression of international trade or on the other hand (depending upon the way, which the national tax legislations chose) to the harmful tax competition, as Raimondos-Moller and Scharf (2002) or Mansori and Weichenrieder (1999) conclude. Raimondos-Moller and Scharf (2002) also derive the condition of Pareto-optimal transfer pricing regulation solution - harmonization of behavior of particular national tax authorities under conditions of compliance with Nash equilibrium conditions. We think that it would be desirable to find a mechanism ensuring the equilibrium even in the conditions of non-cooperative behavior of tax authorities.

Further we can find literature discussing the effectiveness of particular methods of transfer pricing regulation. For example Sansing (1999) concludes that method of transfer pricing regulation systematically influences profit allocation and that methods based on profit split or profit margin act in favor of the countries with higher taxation in this case. Similarly Schjelderup and Weichenrieder (1999) conclude that the use of methods based on profit split causes distortions in the pricing and international trade. Wellisch (2003) concludes that standard methods (arms-length price based methods) cause suboptimal results of decisionmaking. 
In our last paper (Buus and Brada, 2008b) we have provided comparison of transfer pricing techniques proposed by OECD (2001) transfer pricing guidelines. The result was that the only transfer pricing methods, which do not distort prices and thus do not lead to pressure to produce lower or higher than optimal quantity of intermediate product (or in other words, which does not cause departure of tax-optimal and profitoptimal quantity of production) is Cost+ method or Comparable Resale Price method with percentage markup/discount. Other methods distort optimal quantity, while the most distortive method was profit split method. We have gained these results using simulation on maximization of profit and tax revenue, while having only profit taxed. It is however clear that the above conclusions about optimality of transfer pricing methods are valid also for other taxes used for taxation of factor cost (capital, labour).

With respect to the contemporary practice and theoretical findings and with respect to the importance of MNEs we consider to be highly desirable to widen the theory of transfer pricing and derive a solution for transfer pricing regulation, that will lead to Pareto-optimal equilibrium even in the case of non-cooperative behavior of particular tax authorities. It can be shown on the latest steps of CEE governments (and even the German government) leading to lower corporate income tax rates, that we cannot expect a cooperative behavior.

When looking for literature, which would help us, we concluded that we would probably have to rely on our own. Firstly the literature on transfer pricing in vertically integrated industries mostly recognizes the marginal cost as the best transfer price (as could be seen above). Secondly most of the conclusions based on which an optimal taxation system could have been found do not provide satisfactory answers. E.g. Haufler and Schjelderup (2000) examine taxation of capital and the possibility of profit shifting via transfer pricing is only one of assumptions of their model, but in the end they come to conclusion that "there will be a symmetric Nash equilitrium with identical corporate tax systems ...., and no transfer pricing occurs in equilibrium” (ibid, p. 317), which is truly unsatisfactory and contradictory to practise, because that would mean that all countries should have identical corporate tax systems to tax heavens. Among the others let us mention (Keen and Wildasin, 2004), who examine tax systems in general. Bond and Samuelson (1989) derive that the preferred tax scheme are tax deductions, which are preferred to tax credits, because of distortive potential of tax credits. The most suitable 
conclusions from our point of view were derived in (Raimondos-Moeller and Scharf, 2002), that the harmonization of transfer pricing rules leads to Pareto-optimization. These conclusions in some cases rely on an assumption that taxation is an instrument to get resources for provision of services (possibly public goods), therefore taxation itself is not harmful.

In this paper we are going to prolong our look into the possible solutions of transfer pricing and multinationals' taxation conundrum as we want to examine some possible designs of tax system from the point of view of robustness to tax evasion via transfer pricing.

\section{Particular taxes vs. transfer pricing}

While considering the design of tax system that would be robust to tax evasion via transfer pricing, we have to take into account that:

1. We cannot expect that tax authorities will closely cooperate, rather we could expect that there will be probably more and more tough tax competition as capital can be more and more easily moved around globe. Unfortunately, as the mobility of capital is increasing and competition of governments for investments is needed to ensure labor for inhabitants, more and more countries, especially in Eastern Europe, but also in Asia, attracts capital by lowering tax rates. This is not however the main threat, as they mostly try to attract real (physical) capital, i.e. need jobs to be created. More dangerous from this point of view are tax heavens (or offshore centers), where the ownership is often not disclosed and only income from operations, in which citizens of the given offshore country are not employed, or which do not take place at the territory of the given offshore is usually untaxed.

2. It is very difficult to estimate arms-length prices, as the base for their estimation is being distort by (often hidden) transaction between integrated companies.

3. In some jurisdictions it is impossible to find out who is owner of a legal person (usually tax heavens), but also in European or North American countries the real proprietors can be hidden behind fictive owners (general power of attorney or notional shares, notional shareholders). 
But our proposal should reflect also requirements on the tax system in general:

1. To minimize deadweight burden (minimize loss of utility for consumers and producers caused by increasing the price of goods via taxation, extensive explanation and analysis by Auerbach, 1982).

2. To avoid double taxation as much as possible. Most of the taxes used nowadays fulfill this requirement, including VAT, at which the VAT paid in price of inputs is deductible unless the inputs were imported (most European countries provide VAT exemption on exported goods).

3. To minimize indirect and direct cost of tax system, i.e. propose system with as few taxes as possible and as simple as possible.

4. Not to increase income inequality, i.e. impose higher tax on higher income. This is generally achieved by ad valorem taxes, even proportional.

5. To respect the taxable capacity, i.e. levy taxes from those, who have the capacity to pay them. That is mostly achieved by income taxes, but as we have shown above, tax on income and return on capital can be equivalent to e.g. VAT. It is however difficult to distinguish highand low-income units (persons) if we introduced VAT-only system, which apparently taxes consumption, but in fact it taxes both consumption and income (as any other tax on income or consumption does).

These requirements mostly look contradictory at the first sight, mostly the minimization of cost of tax system vs. minimization of deadweight loss. But we can show some arguments against the commonly accepted thesis that one big tax creates higher deadweight loss than two smaller taxes.

\section{Deadweight loss and factor cost distortions}

Requirement to minimize deadweight burden is often understood as to impose rather several small taxes instead of one big tax, for example tax labor, profits, interest and value added, using smaller tax rates instead of using high value added tax (VAT) rate on all operations. That is however 
not true as every general consumption tax is split between consumers (increase of price of goods), producers (decreased income after tax) and further increases factor cost per monetary unit of production to the level where marginal productivity of all factors is the same et vice versa for income taxes (cp. Auerbach, 2006).

Incidence of big tax imposed only on one factor would be more complicated case and would require some mathematics as it shifts to the other factor market through shift of demand for that factor (up due to increased price of the other factor and left due to the decreased quantity of final goods sold) and might increase or even decrease equilibrium price and quantity of the untaxed factor. That depends upon shape and slope of demand and supply of (for) the particular factor (thus also marginal rate of technical substitution of production factors) as well as those properties of the final good supply and demand (see Auerbach, 1982 or Fullerton and Metcalf, 2002). Results of newest empirical research (Desai and Foley and Hines, 2007 or Felix, 2007) suggest that rising or imposing corporate income tax makes capital flee the country, thus decreasing equilibrium demand for work and wages. The negative effect of corporate income taxation on wages is much higher (in monetary terms) than positive effect of rising corporate tax. This effect is usually attributed mostly to high mobility of capital. On the other hand several authors show that the taxation of labor is borne fully by it either in form of wage (Gruber, 1997) if tax burden lowered or partially by wage and partially by employment, due to downward wage rigidity (Kugler and Kugler, 2003). It is worth mentioning that taxes imposed on particular production factors have the potential to distort factor markets as they change relative prices of factors, thus changing marginal rate of technical substitution. VAT is less distortive than combination of personal and corporate income taxes, thus providing less space for active fiscal policy of government (Ballard and Scholz and Shoven, 1987). However, if the tax (e.g. personal income tax) were of the same amount as the (e.g.) VAT in total, it would again shift also supply of the final product and would cause also deadweight loss at the market of final goods. Higher deadweight loss at the market of taxed input factor might then be offset (question is whether partially or fully, but we cannot resolve that without knowledge of demand and supply functions at that particular market) by increased economic surplus at the market of untaxed factor. Results depend entirely on the conditions (supply and demand elasticity) at the factor markets and at the market of final goods. However, from the purely national point of view, taxation of personal income causes increased surplus mostly at capital. 
From one point of view the use of one big general tax (VAT) instead of corporate and personal income taxes is beneficial because it does not distort factor cost, thus does not hamper production efficiency. On the other hand there can be large gap between social cost of existence of particular production factor and income from its taxation because marginal rate of technical substitution does not have to have any relation to utility from public goods that production factors enjoy.

The question of progressivity of VAT (thus respecting of the principle of taxable capacity) was examined before, with the most frequent conclusion that VAT is in the end proportional or slightly progressive when viewed from the life-long perspective (e.g. Casperen and Metcalf, 1993). But even if we would look at the problem from the short-term perspective, it would not be so complicated to construct VAT as progressive by introducing 2 stages of VAT - first is borne by businesses and would consist of quite high VAT, the second then is refund of part or whole VAT for some goods up to certain amount (see Hall, 2005).

\section{Profit shifting and VAT}

From the point of view of possibility to evade tax through transfer pricing, tax with less sensitive tax base would be more advantageous. Such a tax could be VAT, in general. The contemporary design of VAT resembles turnover tax with tax credits (the possibility to deduct tax paid before, included in the price of goods). This property makes this tax very difficult to evade, because at the imported goods (in EU it is goods coming from outside EU) importer has to tax the goods when imported, regardless of the VAT paid before in any third country. Let us take look at VAT base, which consists of price of labor and price of capital, if we slightly simplified it. VAT therefore taxes labor and interest paid on debt, which are usually parts of value added not possible to distort by transfer pricing easily. However, profits can be shifted using transfer pricing, therefore we can not stop impact of tax-evasive transfer pricing by using tax with less sensitive tax base, unless the imported goods are taxed at entry of the country (which is the case of VAT). This property of VAT makes it possible to evade tax by selling low-priced product to tax heaven, but not to evade tax by importing high-priced goods from tax heaven (offshore), even though they have gone through tax heaven only fictively. The important condition of capability to eliminate effect of profit shifting at imported goods is that they are consumed (or more generally sold to VAT non-payer). It is also worth mentioning that this 
design allows us to avoid use of ad valorem tariffs because VAT has similar properties (therefore tax system can be simplified while having the same revenues and their dynamics).

Finally, VAT in the form used in European Union (destination principle, i.e. in fact turnover tax with tax credits) has the great property that it does not disqualify domestic production, if the tax rate is higher than in other countries unless the cross-border consumer purchases (Sinn, 1990) et vice versa. Such a comparative disadvantage would be apparently caused by combination of high personal income tax and high corporate income tax with low VAT. In fact, system with high VAT and low personal income tax and corporate income tax would disqualify (increase price) of imports from countries with high income taxes and low VAT.

The other possibility to improve tax revenue so that it would not be sensitive to profit shifting is to tax personal income by high tax rate and not to tax or tax by low rate the corporate income. Physical capital is always more difficult to move or hide than money (cp. Desai and Foley and Hines, 2007 or Felix, 2007). On the other hand even though this solution is partly used (labor taxation varies around $40-60 \%$, measured by all taxes on personal income in most European countries), it is not used to its full extent. Not only would be that difficult to politically sustain such a tax system, but in the end it would lead to high degree of substitution of labor by capital, although the marginal factor cost would then be the same if labor and capital markets were competitive markets. Some authors advise to use VAT even more within developing countries (Zolt and Bird, 2005) as it does not discourage so much from economic activity and is welfare-improving compared to income taxes even in the long run, if adopted in its pure form (Emini, 2000).

Tax system with high VAT accompanied by low labor and capital taxation (which could be progressive) and some excises or ecological taxes on inferior goods (tobacco, alcohol, greenhouse gasses or their sources) seems to be quite interesting option to minimize tax impact of profit shifting if used to tax imports. However, there are several other ways of profit shifting, not only by importing tangible or intangible goods:

1. through exporting low-priced goods and services,

2. through financial transactions, 
as financial transactions, including insurance, are exempt from VAT and VAT is usually refund if the taxed goods and services are exported (to encourage export-oriented companies).

If one exports low-priced goods and services, he usually exports them (at least administratively) into country with low or no taxation, where these goods or services miraculously gain value and then they are sold in third country. That could be partly resolved by some blacklist of tax heavens, export into which precludes VAT refund or, more generally, by refunding only that amount of VAT, that has been proven and paid at the border of the import country (problem would occur if both export and import country used system of tax credits for the same transaction, i.e. export country for exports and import country for imports). However, even use of VAT advantages to their full extent cannot avoid profit shifting if we considered our country being in the middle of production chain, which would consist of vertically integrated companies (moreover maybe without ability to find out about their integration). Indeed it will make the profit shifting less advantageous if system of tax credits was applied at exports as well as at imports. Then re-export through tax heaven would cause VAT to be paid twice if the origin and destination country were both using tax credits at imports and exports - once on the value of exports to tax heaven and for the second time on the value of imports from tax heaven to third country.

An option for taxation of the financial transactions is to use VAT too, but it would be quite complicated to distinguish transactions, which mean paying for goods, and transactions, which mean lending, borrowings or even payments of interest or dividends. Income tax levied at the source is much more suitable for financial transactions, than VAT.

What would be consequences of the proposed tax system? First of all, VAT is one of the uneasiest taxes to evade, because of its tax-creditnature. The less VAT pays producer of intermediate good, the more pays then producer of final goods, who uses the intermediate goods for production (et vice versa), ceteris paribus. Secondly, tax is enumerated at each invoice so that it can be easily tracked. Thirdly, it impacts all production factors (labor, capital) according to the way market splits it between them (i.e. according to supply and demand elasticity at factor markets), so that it does not distort choice of factors, resp. ratio in which they are used in production. Finally this system makes the other countries to accept it too and if this system was spread widely, it gives to the low- 
tax countries no advantage arising from low taxation (due to the tax-credit nature of VAT), while this system avoids double taxation at the same time.

Off course, it would be possible to design other taxes in the same way as VAT (tax credits), however it would entirely change their nature as income taxes are rather based on tax deductions and tax credits system applies only in special cases (mostly taxes on revenues on capital).

There is one strong drawback of VAT as universal tax replacing income taxes partly or fully - we cannot use system of tax claims intertemporarilly, as there are some goods and services that ought to be taxed by reduced VAT rate (mostly basic foods and drinks). The intertemporal use of tax claims might look that way that taxpayer can use the excessive tax credit to lower tax obligation in subsequent periods, but cannot require tax authority to pay him the excessive tax credit. Subjects providing those goods and services, taxed by reduced VAT, often have most of the inputs taxed by basic VAT rate so that excessive tax claims are permanent at them. But the intertemporal version of tax credits is used in some way, because revenue authorities often use all the possible instruments included in law, that enable them to postpone payment for VAT excessive claims or cast doubt on them.

In the end VAT can be trickier instrument to tackle profit shifting, than it seems at the first sight, because it would silently move the tax burden towards capital in most European countries (labor taxation is mostly higher than taxation of capital), which means more volatile tax income. Suprisingly VAT does not repeal capital as much as corporate income tax, probably because

1. it is refunded at exports, so that it does not hamper competitive advantage at exports,

2. it is levied at imports to full extent, so that it is not detrimental to competitive advantage at goods sold in country of origin (all goods are taxed by the same VAT rate), and

3 . it is not so apparent.

Carrey and Rabesona (2002) provide indirect empirical proof (see $\mathrm{p}$. $144 \mathrm{ibid}, \mathrm{cp}$. to the incidence of corporate income tax). If one wanted to evade VAT, the easiest way with the least risk would be to undervalue his products and try to overvalue inputs (in context of this paper via transfer 
pricing). If system of tax credits were strictly used at cross-border transactions (both exports and imports), only undervaluation of (of both imported and exported goods or services) would make sense for the evader. It is also advantageous that in most countries VAT is paid on quarterly or monthly basis. At VAT long-term excessive deductions are almost impossible (if abstracting from cases with basic VAT rate at inputs and reduced rate at outputs), because one would have go bankrupt in long term in such case. In the end empirical research shows that VAT is less sensitive than income- or cash-flow-based taxes (Gordon and Nielsen, 1997).

Another way to narrow space for tax evasion could be to use more extensively excises, which are defined in fixed amount per quantity of goods sold. This is however possible only for limited amount of goods, which are of homogenous nature. Otherwise it would be almost impossible to manage such a system, because of many goods and services that are very similar at the first look, but very different in their value for buyer, therefore not easily distinguishable. That might provide even larger space for tax evasion than VAT with tax credits for cross-border transactions.

\section{Wider use of tax credits}

We have extensively discussed VAT in the previous paragraphs because of its nature based on tax credits. More extensive use of tax credits within VAT could eliminate some of its unpleasant properties like the possibility to evade the whole VAT through transfer pricing (although this possibility is limited by short interval between VAT payments as we have shown above). If the payroll tax was obligatory to pay and could be credited against the VAT rate (which could be under our proposition between $30 \%-45 \%$, depending on share of government expenditures on GDP), at least payroll tax would be paid always. The same system would not be of use in the case of corporate income tax.

The proposed solution is not very new, as VAT almost in the form we have described above exists, at least within European Union (and 125 other countries in less or more modified form). What is new about our solution is

1. The proposal to introduce tax credits for exports into countries, which have not adopted the same system (full VAT payment or 
tax credits) at the import side or do not levy VAT at all. In such case exporter would pay full VAT less the proven amount of VAT paid at import to the third country that was not refunded. If one exported undervalued goods to tax heaven, he would get no VAT back under such system.

2. The proposal to introduce higher VAT taxation that would partly replace corporate income and personal income taxes.

3. The use of tax credits of payroll or personal income taxes against VAT, which could be undertaken either by crediting of payroll taxes to VAT at companies or crediting VAT paid in price of goods and services to payroll taxes (done at consumers). The latter system, i.e. crediting VAT paid in price of goods and services to payroll taxes (done at consumers) would be more enforceable as it brings in "third-party reporting of information that facilitates enforcement of the taxation" (Slemrod, 2007).

4. The use of tax credits of VAT intertemporarilly.

These steps would significantly simplify tax system, yet they would also diminish space for tax evasion via profit shifting (transfer pricing).

Several authors advocate for wider use of VAT, mostly U.S.-based authors, as United States of America do not use VAT at all (it was completely abolished in Michigan in 2009, instead sales tax is used in most states). Among these we can count almost all authors of papers in (Auerbach and Hasset, 2005), Boeters and Böhringer and Büttner and Kraus (2006), who argue by increased welfare if VAT replaced substantial part of income taxes, or Metcalf (1995), but also Auerbach (2006).

\section{Drawbacks of tax credits and VAT}

Higher taxation is usually present at developed countries, whereas countries in transition or developing countries have lower tax burden et vice versa (see Fig. 1). 
Fig. 1: Total tax burden and GDP/capita in OECD countries, 2003

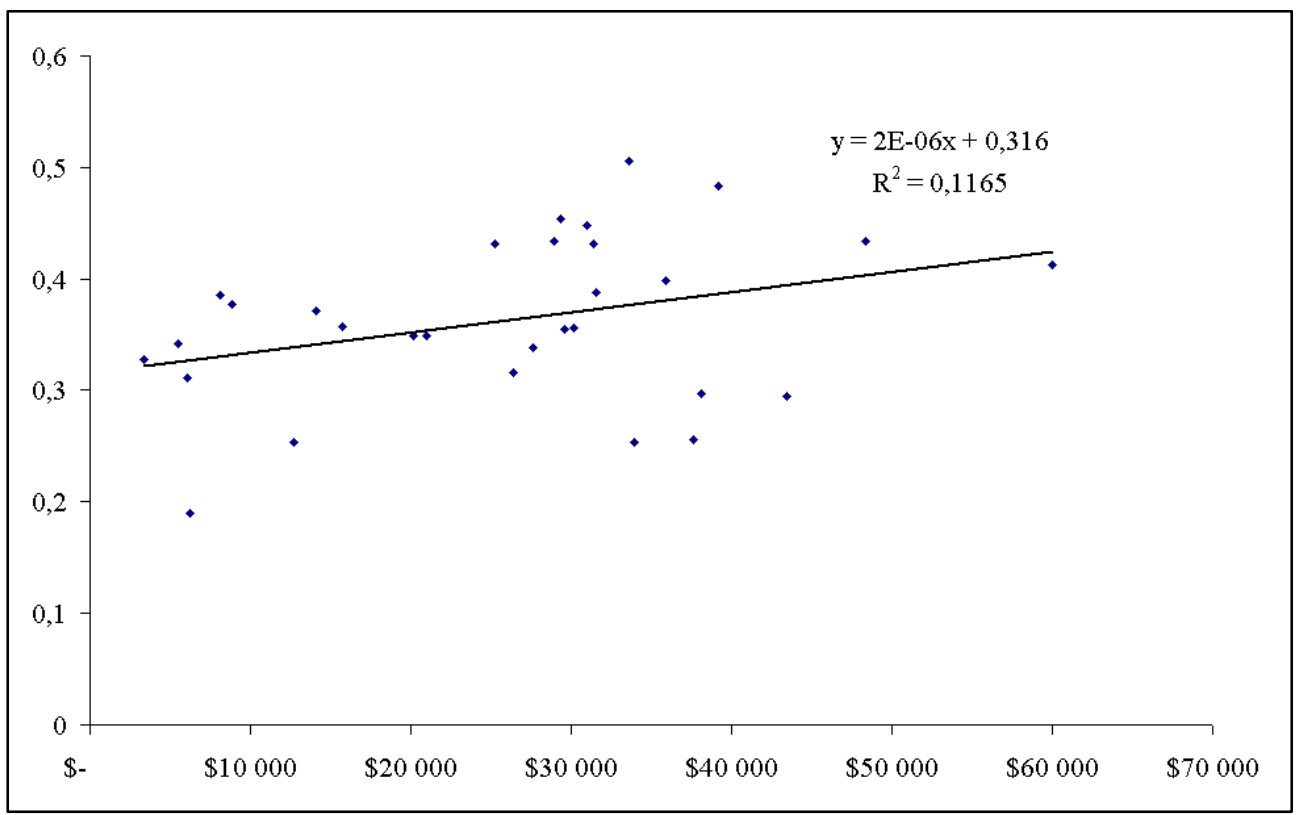

Source: OECD (2004)

This reflects, according to our opinion, the stage of development of the social system, regulation, regulatory framework, health care system, security and defense etc. We can say that based on some social consensus government provides the desired scope of services. The proposed system of tax credits, which is, by the way, used in U.S.A. for FDI (foreign direct investments) of U.S. corporations outside U.S. transfers the cost of existence of state from more developed countries (countries with higher tax burden) to less developed countries (countries with lower tax burden). This is the way VAT works even nowadays in international trade, so that we do not propose anything new harmful and proposals of general consumption tax, which would not use tax credits like VAT, would be even more harmful in these terms. On the other hand the strategy of lowincome countries might be to have low taxes, especially taxes, which cannot be credited in a way VAT is (corporate income tax), to attract capital and increase employment. The opposite effect at the consumer (high income) countries is decrease of employment and increased cost of social system. Use of tax credits prevents such behavior. In the end, VAT with extensive use of tax credits is also strong response: 
1. useable by countries with high degree of openness (like Czech republic is),

2. to policies of countries, which have low labor cost and use protectionist policies preventing or avoiding foreign companies to gain control stake in profitable companies (like China does),

3. to illegal use of intellectual property (again mostly the case of China, cp. e.g. Sybert, 2008 or Ratner, 2008 or Holstein, 2007 or Athanasakou, 2007, although Yang and Yen, 2009 claim that China has made some steps for better intellectual property protection).

Bond and Samuelson (1989) conclude that one of the main drawbacks of tax credits is that they distort prices. It is surely true; let us remind what was written in the previous paragraph about the cost of state. However we have not found any instrument that could compete tax credits in preventing profit shifting (i.e. distortive transfer pricing) so far. It is questionable then what effect prevails - whether the one that prevents price distortion caused by tax-evasive transfer pricing or the other, which causes price distortions.

Let us also mention that VAT with extensive use of tax credits makes entrepreneurs more impartial regarding taxation of imported and domestically produced goods, because means the same tax burden on both of them. That unfortunately does not hold regarding choice between production abroad (in any third country) and exports of domestically produced goods unless exports are free of VAT, which is mostly the case of VAT systems nowadays but which counterfeits the above proposed system of tax credits.

\section{Mathematical representation of tax credits properties}

Let us compare tax systems, which would lack VAT (like that one in USA) and hypothetical system that would consist only of VAT. We can describe price of any product as sum of prices of inputs and profits of all producers, who take part at the production of either final or intermediate product, so that $\mathrm{i}$-th product in row is priced:

$$
p_{i}=p_{i-1}+\sum_{X \in F}\left(p_{X, i} \cdot X_{i}\right)
$$


where $p_{i}=$ price of product, either intermediate or final,

$i \quad=$ ordinal number, representing the order of producer in supply chain i.e. $i \in \mathfrak{\aleph}$

$X \quad=$ quantity of product,

$F=\begin{aligned} & \text { set of production factors, i.e. labor, capital, } \\ & \text { eventually land. }\end{aligned}$

If input factors are taxed, then price of factor consists of price of factor without taxation and tax, i.e.

$$
p_{X, i}=x_{i}+T_{i}\left(x_{i}\right) \text {, }
$$

$$
\text { where } \begin{aligned}
x_{i} & =\text { price of untaxed input factor } X \text { used by } \mathrm{i}-\text { th } \\
T_{i}\left(x_{i}\right)= & \text { tax in monetary terms. }
\end{aligned}
$$

The common design of ad valorem tax is use of tax rate constant within some intervals, but let us simplify to proportional tax (which, regarding marginal tax rate, has within those intervals the same properties as sliding progressive tax). Then

$$
p_{X, i}=x_{i} \cdot\left(1+t_{x, i}\right)
$$

$$
\begin{aligned}
& \text { where } t_{x, i}= \text { tax rate imposed input factor } X \text { used by } \mathrm{i} \text {-th } \\
& \text { producer in row }
\end{aligned}
$$

and price of the $\mathrm{i}$-th product in row is

$$
p_{i}=p_{i-1}+\sum_{X \in F}\left[x_{i} \cdot\left(1+t_{x, i}\right) \cdot X_{i}\right]
$$

but tax credits have different nature. The above representation is to be attributed to system with tax deductions like personal and corporate income tax. If we used value added tax along with tax credits in the way we described above (except for crediting payroll taxes against VAT) we could write the price of product produced by i-th producer including tax (still assuming proportional VAT, where the tax rates for all factors are the same), in the following way: 


$$
p_{i}=\sum_{X \in F}\left[p_{x, i-1} \cdot \frac{\left(1+\max \left(t_{i} ; t_{i-1}\right)\right)}{\left(1+t_{i-1}\right)}+x_{i} \cdot\left(1+t_{i}\right)\right] \text {, }
$$

because it would be very costly and cumbersome to observe effective tax rates further than at the nearest predecessor and nearest ancestor. Exporter or importer could get information about VAT paid on exported goods in destination country and on imported goods at the origin country, but further tax is unobservable for him. We can see that difference is only in the tax levied from factors used in abroad production. If foreign tax rate experienced by nearest predecessor or ancestor is lower for any factor than the one experienced by $j$-th company, $j$-th government can reduce tax base or tax rate while achieving the same tax income.

Let us assume that the above-described system (5) was accepted by all countries in system (e.g. 2, 3 or more). Moving more production to country with low taxation will help the producer under conditions of (5), if and only if no further subsequent country in production chain has higher tax rate. The result would be that most goods and services would be consumed in the country of their origin. Also it would be probably unable to apportion personal and corporate income taxes paid abroad to certain product so that this system would be disadvantageous for countries with high personal and corporate income taxes and would induce wider use of VAT. It might seem that under conditions of (5) countries would be also encouraged to increase tax rates above equilibrium. Under conditions of (5) only factor cost matter in subsequent countries, but predecessor has incentive to lower tax rate to the level of ancestor, because otherwise products exported by producers residing there would not be competitive.

Decoupling the transfer prices from sum of factor cost plus tax would not be of use either. As tax heavens allow only companies, which do not use domestic resources to pay very low or no taxes, tax heaven has to be somewhere in the middle of supply chain or immediately before exporting to the country of final consumption. Goods "exported" to tax heaven will be underpriced, but (5) cannot avoid such tax evasion; it can diminish it. Products "imported" from tax heaven will be overpriced; in this case (5) fits perfectly and does not allow for any tax evasion. That would make even the underpricing of goods "exported" to tax heaven senseless risky (we assume that along with the above described system, transfer pricing rules are applied and enforced by national tax authorities), because no 
reward in terms of tax saving would be for it. If we described the consequences in very simplified way, it would be that what shall be taxed in the country of origin (before tax heaven), that will be taxed there and vice versa.

Contrary to contemporary practice we propose taxation of exported goods in (5), due to the idea that state provides some services to owners of production factors, who can therefore realize and fully enjoy price paid for their factors (security, healthcare, defense, etc.).

\section{Conclusions}

To conclude: although some authors point at the possibility that tax credits distort prices, we do think that the positive aspects of VAT as the strongest credit-based tax in the end overweigh and that wider spread of the system proposed by us would significantly reduce utility of MNEs from using transfer prices for profit shifting. In the short term a more extensive use of VAT along with tax credits could be detrimental to foreign trade and especially to countries, which attract capital with low corporate income taxes, but in the long run its nature enforces the other countries to adopt it too, which would be in the end Pareto-improvement (with respect to the power of income taxes to distort factor cost). To fully utilize properties of VAT, wide use of tax credits is desirable. Therefore we propose the payroll taxes and personal income taxes to be credited against VAT (in case of corporate income tax it is senseless) and VAT paid at the export-side of border to be credited against VAT that is paid at import-side of the border. Exported goods and services should be taxed fully by domestic VAT rate. In the world where all countries are both exporters and importers this would not lead to harmful tax competition in upside direction (because that would make exports uncompetitive) nor to harmful tax competition in opposite way, because taxation of larger-than necessary part of value added in low-tax country would not yield any gain (nor even if the tax evasion was realized using transfer prices). The proposed solution should be therefore quite stable.

We are going to outline more rigorous examination of VAT from the quantitative point of view in our subsequent papers as well as test the proposed solution in terms of reaching Pareto-optimal state that would prevent harmful tax competition and tax-evasive transfer pricing. 
Buus, T. - Brada, J.: VAT and Tax Credits: A Way to Eliminate Tax-Evasive Use of Transfer Prices?

\section{References}

[1] Athanasakou, K. (2007): China IPR Enforcement: Hard as Steel or Soft as Tofu? Bringing the Question to the WTO under Trips. Georgetown Journal of International Law, 2007, vol. 39, no. 1, pp. 217-245.

[2] Auerbach, A. J. (1982): The Theory of Excess Burden and Optimal Taxation. [on-line], Washington, D. C., National Bureau of Economic Research, c1982. [cit. 10 ${ }^{\text {th }}$ January, 2010], <http://www.nber.org/papers/w1025.pdf>.

[3] Auerbach, A. J. (2006): The Future of Capital Income Taxation. [on-line]. 2007. Berkeley, University of California, c2006, [cit. $10^{\text {th }}$ October, 2009],

$<$ http://www.econ.berkeley.edu/ auerbach/The $\% 20$ Future $\% 20$ of $\% 20$ Capital\%20Income\%20Taxation.doc.pdf>

[4] Auerbach, A. J. - Hasset, K. A. (2005): Toward Fundamental Tax Reform. Washington, D.C., American Enterprise Institute for Public Policy Research, 2005.

[5] Baldenius, T. - Melumad, N. D. - Reichelstein, S. J. (2004): Integrating Managerial and Tax Objectives in Transfer Pricing. Accounting Review, 2004, vol. 79, no. 3, pp. 591-615.

[6] Ballard, C. L. - Scholz, J. K. - Shoven, J. B. (1987): The Value-Added Tax: A General Equilibrium Look at Its Efficiency and Incidence. In: Feldstein, M. (ed.): The Effects of Taxation on Capital Accumulation. Chicago, University of Chicago Press, pp. 445-480, 1987.

[7] Bartelsman, E.J. - Beetsma, R.M.W.J. (2003): Why Pay More? Corporate Tax Avoidance through Transfer Pricing in OECD Countries. Journal of Public Economics, 2003, vol. 87, no. 9, pp. 2225-2252.

[8] Bernard, A. B. - Jensen, J.B. - Schott, P. K. (2006): Transfer Pricing by U.S.-based Multinational Firms. [on-line], Washington, D. C., National Bureau of Economic Research, c2004. [cit. 10 ${ }^{\text {th }}$ January, 2010], <http://papers.nber.org/papers/w12493.pdf>.

[9] Boeters, S. - Böhringer, C. - Büttner, T. - Kraus, M. (2006): Economic Effects of VAT Reform in Germany. [on-line], Mannheim, Centre for European Economic Research, c2006, [cit. 10 ${ }^{\text {th }}$ January, 2010], <ftp://ftp.zew.de/pub/zew-docs/dp/dp06030.pdf> 
[10] Bond, E. W. - Samuelson, L. (1989): Strategic Behaviour and the Rules for International Taxation of Capital. The Economic Journal, 1989, vol. 99, no. 398, pp. 1099-1111.

[11] Buus, T. - Brada, J. (2008a): On the Necessity of Using Average Cost as a Base for Transfer Price. European Financial and Accounting Journal, 2008, vol. 3, no. 3, pp. 79-94.

[12] Buus, T. - Brada, J. (2008b): O vlastnostech metod stanovení transferových cen. Český finanční a účetní časopis, 2008, vol. 3, no. 3, pp. 39-55.

[13] Casperen, E. - Metcalf, G (1993): Is Value Added Tax Progressive? [on-line], Washington, D. C., National Bureau of Economic Research, c1993, [cit. 10 ${ }^{\text {th }}$ January, 2010], <http://www.nber.org/papers/w4387.pdf>.

[14] Desai, M. A. - Foley, C. F. - Hines, J. R. (2007): Labor and Capital Shares of the Corporate Tax Burden: International Evidence. [on-line]. Boston,, Harvard Business School, c2007, [cit. 10 January, 2010], <www.people.hbs.edu/mdesai/PDFs/Labor\%20and\%20Capital.pdf〉.

[15] Eden, L. - Rodriguez, P. (2004): How Weak are the Signals? International price indices and multinational enterprises. Journal of International Business Studies, 2004, vol. 35, no. 1, pp. 61-74.

[16] Emini, C. A. (2000): Long Run Vs Short Run Effects of a Value Added Tax: A Computable General Equilibrium Assessment for Cameroon. [on-line], Montreál, Centre interuniversitaire sur le risque, les politiques économiques et l'emploi, c2000, [cit. 10 ${ }^{\text {th }}$ January, 2010], 〈http://www.crefa.ecn.ulaval.ca/cahier/0012.pdf >.

[17] Felix, R. A. (2007): Passing the Burden: Corporate Tax Incidence in Open Economies. [on-line]. Kansas City, Federal Reserve Bank of Kansas City, c2007, [cit. $10^{\text {th }}$ January, 2010], <https://www.kansascityfed.org/Publicat/RegionalRWP/RRWP0701.pdf $>$.

[18] Fullerton, D. - Metcalf, G.E. (2002): Tax Incidence. [on-line], Washington, D. C., National Bureau of Economic Research, c1993, [cit. 10 ${ }^{\text {th }}$ January, 2010], <http://www.nber.org/papers/w3750.pdf $>$.

[19] Gordon, R. H. - Nielsen, S. B. (1997): Tax Evasion in an Open Economy: Value Added vs. Income Taxation. Journal of Public Economics, 1997, vol. 66, no. 2, pp. 173-197 
Buus, T. - Brada, J.: VAT and Tax Credits: A Way to Eliminate Tax-Evasive Use of Transfer Prices?

[20] Gresik, T. A. (2001): The Taxing Task of Taxing Transnationals. Journal of Economic Literature, 2001, vol. 39, no. 3, pp. 800-838.

[21] Gruber, J. (1997): The Incidence of Payroll Taxation: Evidence from Chile. Journal of Labor Economics, 1997, vol. 15, no. 3, pp. 72-101.

[22] Hall, R. E. (2005): Guidelines for Tax Reform: The Simple, Progressive Value-Added Consumption Tax. In: Auerbach, A. J. Hasset, K. A. (eds.): Toward Fundamental Tax Reform. Washington, D. C., American Enterprise Institute for Public Policy Research, 2005, pp. 70-80.

[23] Haufler, A. - Schjelderup, G. (2000): Corporate tax systems and cross country profit shifting. Oxford Economic Papers, 2000, vol. 52, no. 2 , pp. 306-325.

[24] Hirshleifer, J. (1956): On the Economics of Transfer Pricing. Journal of Business, 1956, vol. 29, no. 3, pp. $172-184$.

[25] Holstein, W. (2007): Protecting the Company Jewels in an Unprotected Country. Research Technology Management, 2007, vol. 50, no. 6; pp. 14-16.

[26] Keen,M.-Wildasin,D.(2004):Pareto-EfficientInternationalTaxation. The American Economic Review, 2004, vol. 94, no. 1, pp. 259-275.

[27] Kugler, A. - Kugler, M. (2003): The Labor Market Effects of Payroll Taxes in a Middle-Income Country: Evidence from Colombia. [on-line]. New York, Social Science Research Network, c1999, [cit. $10^{\text {th }}$ January, 2010], <http://papers.ssrn.com/sol3/papers.cfm?abstract_id=435380>

[28] Mansori, K. S. - Weichenrieder, A. J. (1999): Tax Competition and Transfer Pricing Disputes. [on-line]. New York, Social Science Research Network, c1999. [cit. 10 ${ }^{\text {th }}$ January, 2010], <http://ssrn.com/abstract=199672>

[29] Metcalf, G. E. (1995): Value-Added Taxation: A Tax whose Time Has Come? The Journal of Economic Perspectives, 1995, vol. 9, no. 1, pp. 121-140.

[30] OECD (2001): Transfer Pricing Guidelines for Multinational Enterprises and Tax Administrations. Paris, Organisation for Economic Co-operation and Development, 2001.

[31] OECD (2004): OECD Revenue Statistics 1965-2004. Paris, Organisation for Economic Co-operation and Development, 2004. 
[32] Pappas, J. L. - Brigham, E. F. - Hirschey, M. (1983): Managerial Economics. Chicago, Dryden Press. 1983.

[33] Raimondos-Moller, P. - Scharf, K. (2002): Transfer pricing rules and competing governments. Oxford Economic Papers, 2002, vol. 54, no. 2. pp. 230-246.

[34] Ratner, M. (2008): China steps up US biotech intellectual property land grab. Nature Biotechnology, 2008, vol. 26, no. 2, pp. 141-142.

[35] Sansing, R. (1999): Relationship-Specific Investments and the Transfer Pricing Paradox. Review of Accounting Studies, 1999, vol. 4, no. 2. pp. 119-134.

[36] Schjelderup, G. - Weichenrieder, A. J. (1999): Trade, Multinationals and Transfer Pricing Regulation. Canadian Journal of Economics, 1999, vol. 32, no. 3, pp. $817-834$.

[37] Schmallenbach, E. (1908): Über Verrechnungspreise. Zeitschrift für handelswissenschaftliche Forschung, 1908/1909, vol. 3, pp. 165-185.

[38] Sinn, H. (1990): Tax Harmonization and Tax Competition in Europe. European Economic Review, 1990, vol. 34, no. 2-3, pp. 489-504.

[39] Slemrod, J. (2007): Cheating Ourselves: The Economics of Tax Evasion. Journal of Economic Perspectives, 2007, vol. 21, no. 1, pp. $25-48$.

[40] Soukup, J. (2003): Mikroekonomická analýza - vybrané kapitoly. Slaný, Melandrium, 2003.

[41] Sybert, R. (2008): IP Protection and Counterfeiting in China. Intellectual Property \& Technology Law Journal, 2009, vol. 20, no. 7, pp. 12-15.

[42] Wellisch, D. (2003): Internationale Verrechnungspreismethoden, Neutralität und die Gewinne multinationaler Unternehmen. Jahrbücher für Nationalökonomie und Statistik, 2003, vol. 223, no. 3. pp. $332-359$.

[43] Yang, W. - Yen, A. (2009): The Dragon Gets New IP Claws: The Latest Amendments to the Chinese Patent Law. Intellectual Property \& Technology Law Journal, 2009, vol. 21, no. 5, pp. 18-21.

[44] Zolt, E. M. - Bird, R. M. (2005): Redistribution via Taxation: The Limited Role of the Personal Income Tax in Developing Countries. UCLA Law Review, 2005, vol. 52, no. 1. pp. 1-72. 


\title{
VAT and Tax Credits: A Way to Eliminate Tax-Evasive Use of Transfer Prices?
}

Tomáš BUUS - Jaroslav BRADA

\begin{abstract}
In this paper we compare income taxes to VAT and tax credits to tax deductions in terms of their ability to distort factor prices, provide fair taxation, avoid tax-evasive transfer pricing and induce Pareto improvement of tax policies. On the base of theoretical discussion and thought experiments we conclude that VAT is due to its nature superior regarding these requirements. We also have found out that a wider use of tax credits within VAT would be useable to prevent profit shifting. Some adjustments of VAT compared to current practice are needed to achieve the best results. More rigorous proofs, both theoretical and empirical are needed.
\end{abstract}

Key words: Tax credits; VAT; Transfer prices; Multinational enterprises; Pareto optimum.

JEL classification: D21, D29, G39. 